\title{
Mapování profesního uplatnění sociálních pedagogů na trhu práce od roku 2005-2011
}

\author{
Professional application of the graduates of Social education and a leisure time at the \\ Faculty od Education, Masaryk University Brno in the labour market (2005-2011)
}

\author{
Petr Soják, Lenka Kristková
}

\begin{abstract}
Anotace:Text se zaměřuje na profesní uplatnění absolventů studijního oboru Sociální pedagogika a volný čas na PdF MU v Brně na trhu práce. Empirická část práce pojednává o dotazníkovém šetření monitorujícím profesní uplatnění zmíněných absolventům na trhu práce. Dále se výzkumné šetření zabývá hodnocením přínosu výše zmíněného studia pro profesní praxi jeho absolventi̊. $\mathrm{K}$ tomuto výzkumnému záměru bylo užito metody výzkumu Qmetodologie.
\end{abstract}

Klíčová slova: Profesní uplatnění sociálních pedagogů na trhu práce, sociální pedagogika, sociální pedagogika a volný čas, absolventi sociální pedagogiky a volného času, př́nos studia Sociální pedagogika a volný čas, dotazníkové šetření, Q-metodologie

\begin{abstract}
The text is focused on professional application of the graduates of Social education and a leisure time at the Faculty of Education, Masaryk University Brno in the labour market. The empirical part deals with a questionnaire research observing a professional application of above mentioned graduates in the labour market. Furthermore, the research is concentrated on evaluation of benefits of above mentioned studies for professional experience of the graduates. In the research was used an Q-methodology approach.
\end{abstract}

Keywords: Professional application of social educators in the labour market, social education, Social education and a leisure time, the graduates of Social education and leisure time, benefits of studies of Social education and a leisure time, a questionnaire research, Qmethodology

\section{1 Úvod}

Katedra sociální pedagogiky Pedagogické fakulty MU nabízí a garantuje odborné studium oboru Sociální pedagogika, a to jak v kombinované, tak prezenční formě studia. Již deset let každoročně studium ukončí desítky sociálních pedagogů, kteří hledají uplatnění na trhu práce. Jejich odborná vybavenost je široká a umožňuje absolventům uplatnit se v mnoha oblastech sociální sféry, nejen ve vztahu k jedincům v tíživé sociální a životní situací nebo k sociálně a kulturně znevýhodněným skupinám obyvatelstva.

Sociální pedagogika je $\mathrm{v}$ českých podmínkách poměrně mladý obor a do katalogu pedagogických profesí se doposud nepodařilo profesi sociálního pedagoga prosadit. Proto se věnují pracovníci katedry sociální pedagogiky ve své výzkumné práci mj. také podmínkám uplatnitelnosti sociálních pedagogů na trhu práce. Sociální pedagogika vymezuje cíle a rozpracovává obsah, formy a metody profesní prrípravy pracovníků pro sociální oblast, kteří realizují sociálně pedagogické činnosti. 
Tento článek mapuje poznatky získané z dotazníkového šetření monitorující profesní uplatnění absolventů sociální pedagogiky na trhu práce. Druhou částí textu jsou výstupy získané na základě Q-metodologie, zabývající se hodnocením př́nosu výše zmíněného studia pro profesní praxi jeho absolventů.

Záměrem empirického výzkumného šetření bylo zmapovat hned dvě oblasti - první je profesní uplatnění absolventů studijního oboru Sociální pedagogika a volný čas - PdF MU v Brně (SOVC) na trhu práce, druhou oblastí je př́nos studia SOVC pro profesní praxi jeho absolventů. Výzkumné šetření tedy objasňuje, kde v praxi a za jakých podmínek se absolventi SOVC uplatňují, jak jsou připraveni pro jejich profesní praxi, jaká je náplň jejich práce, se kterou cílovou skupinou pracují.

Výzkumný soubor tvořili absolventi studijního oboru Sociální pedagogika a volný čas na PdF MU, studijních programů B-PD SOVC - tříletý bakalářský program (prezenční forma) a PD SOVC - navazující dvouletý magisterský program (prezenční forma). Vzorek mapoval roky 2005, 2006, 2007, 2008, 2009, 2010, posléze i 2011.

Pro první část výzkumu byla použita metoda dotazníkového šetření a následné statistické zpracování dat z něj získaných.

Dotazník, jako nástroj sběru dat pro tuto část výzkumu se skládal z 22 hlavních položek a 5 podotázek. Obsah a znění položek vznikaly na základě výzkumných otázek, kterých bylo v této první části výzkumu 7 . V dotazníku jsou použity především otázky polouzavřené, dále také uzavřené a několik málo položek otevřených. Ty však považujeme za stěžejní a odpovědi na ně za informačně nejvíce hodnotné. $Z$ polytomických položek byly použity především výběrové a jedna položka výčtová. Většina položek dotazníku zjišt’ují fakta, jsou však také použity otázky zaměřující se na mínění a postoje.

Metoda dotazníkového šetrení byla zvolena $z$ důvodů nutnosti oslovit velký počet respondentů jeho výhod poměrně snadné administrace a kvantifikovatelnosti získaných údajů.

Pro naplnění druhého výzkumného cíle byla zvolena metoda Q-metodologie. Východiskem pro tvorbu. tzv. Q-typů byly polostrukturované rozhovory s absolventy SOVC a jejich kvalitativní analýza. Následné statistické zpracování dat získaných z Q-trí́dění mělo za cíl zjistit, jak respondenti posuzují své vědomosti a dovednosti získané v rámci studia SOVC v souvislosti s jejich profesním uplatněním na trhu práce.

Polostrukturované rozhovory byly uskutečněny se třemi absolventy bakalářského i navazujícího magisterského stupně studijního oboru SOVC v zastoupení všech třech studijních specializací tohoto oboru. Po transkripci audio nahrávek byla provedena kvalitativní analýza otevřeného kódování získaných dat. Kritériem tvorby a následně užšího výběru Q-typů bylo nejčastěji se vyskytující témata. Zároveň jsme však považovali za důležité zachovat různorodost názorů o jednotlivých jevech.

Původním cílem výzkumného šetření bylo zjistit, jaký mělo studium SOVC přínos pro jejich absolventy po stránce profesní, v rozhovorech se velmi výrazně objevovali výpovědi týkající se také př́nosu v rovině osobnostní a hodnotové. Zhodnotili jsme tedy jako výzkumně přínosné tento výzkumný cíl rozšsiřit o již zmíněné roviny a to následovně: Zjistit, jaký mělo studium SOVC přínos pro jejich absolventy pro stránce profesní, osobnostní i hodnotové.

Jako interpretační nástroj pro kategorizaci Q-typů jsme zvolili druhy výukových cílů kognitivní, afektivní, psychomotorické. 
Při kvalitativní analýze rozhovorů vzniklo cca 100 Q-typů, z nichž bylo vybráno do užšího výběru 42 (pod každý výukový cíl spadalo 14 Q-typů), které byly použity pro samotné výzkumné šetření.

Dotazníkové šetření i Q-trídění bylo zpracováno do jednoho interaktivního dotazovacího nástroje (dále pouze IDN), obě části IDN čili metody sběru dat byly vzájemně provázané. Druhá část IDN - Q-třídění měla několik fází:

1. Postupné zobrazování výroků a hodnocení respondenty dle míry souhlasu na škále 0 $100 \%$. Toto hodnocení bylo nastaveno na $5 \%$ toleranci.

2. V této fázi se respondentovi zobrazovaly výroky, jejichž klasifikace respondentem se nelišila více než $5 \%$. U nich měl ohodnotit, se kterým z přednožených opravdu souhlasí nejvíce.

3. Řazení Q-typů do určené distribuce dle statistické výhodnosti, tzn. Gaussovy křivky. Respondenti řadily výroky do sedmi sloupců o hodnotách -3 do +3 , jež znázorňovali míru souhlasu s předloženým výrokem.

Po dokončení a naprogramování IDN byla provedena pilotáž na vzorku šesti respondentů. $\mathrm{Na}$ základě ní byly provedeny dodatečné úpravy, především ve formulaci Q-typů.

Pro samotné výzkumné šetření bylo osloveno 190 respondentů, tedy absolventů SOVC. Jednalo se o absolventy bakalářských nebo navazujících magisterských studijních stupňů, poprŕípadě obou. Výzkumný vzorek byl zúžen na absolventy z roku 2005-2011.

Kontakty na respondenty byly získávány několika způsoby:

1. Od informačního technika PdF MU byl získán seznam absolventů SOVC v požadovaném šestiletém období s jejich univerzitními čísly. Na základě těchto čísel lze vytvořit univerzitní e-mailové adresy.

2. Dále byla založena skupina Absolvent sociální pedagogiky prostřednictvím webového systému Facebook. V době zahájení sběru dat čítala tato skupina 82 absolventů.

3. Také bylo využito osobních kontaktů výzkumníka a dále jejich kontaktů - metoda tzv. sněhová koule.

Pro orientaci ve výzkumných postupech přikládáme schematické zobrazení výzkumného designu viz Obrázek 1. Pro jeho bližší pochopení je možné nahlédnout př́imo do DP, ze které tento článek vychází (viz Kristková, 2011).

\section{Analýza dat a výstupy výzkumného šetření}

\subsection{Dotazníkové šetření}

Po kontrole správnosti a dostatečnosti vyplnění dotazníku byla data $\mathrm{z}$ IDN převedena do programu MS Excel, který nám posloužil jako nástroj pro provedení deskriptivní statistiky. Nejčastěji se jednalo o analýzu četností. Z dotazníkového šetření jsme získali velké množství dílčích výstupů. Zde se pokusíme zmínit jen ty nejpodstatnější a seznámit čtenáře spíše s jakýmsi celkovým pohledem na stav zkoumané problematiky. Za podstatný výstup považujeme souvislost uplatnění absolventů s oborem SOVC viz graf na obrázku 2. 


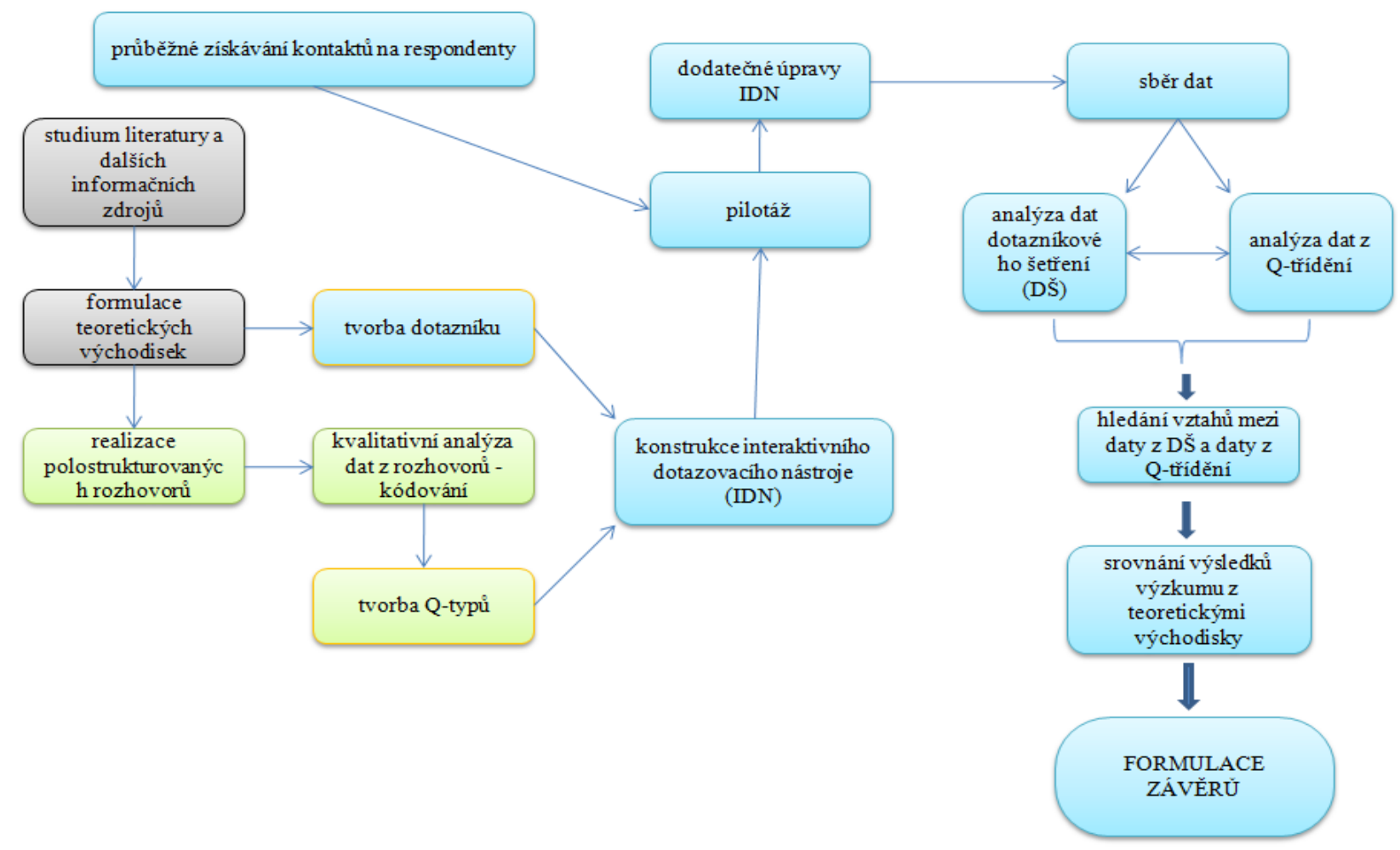

Obrázek 1. Schéma výzkumného designu

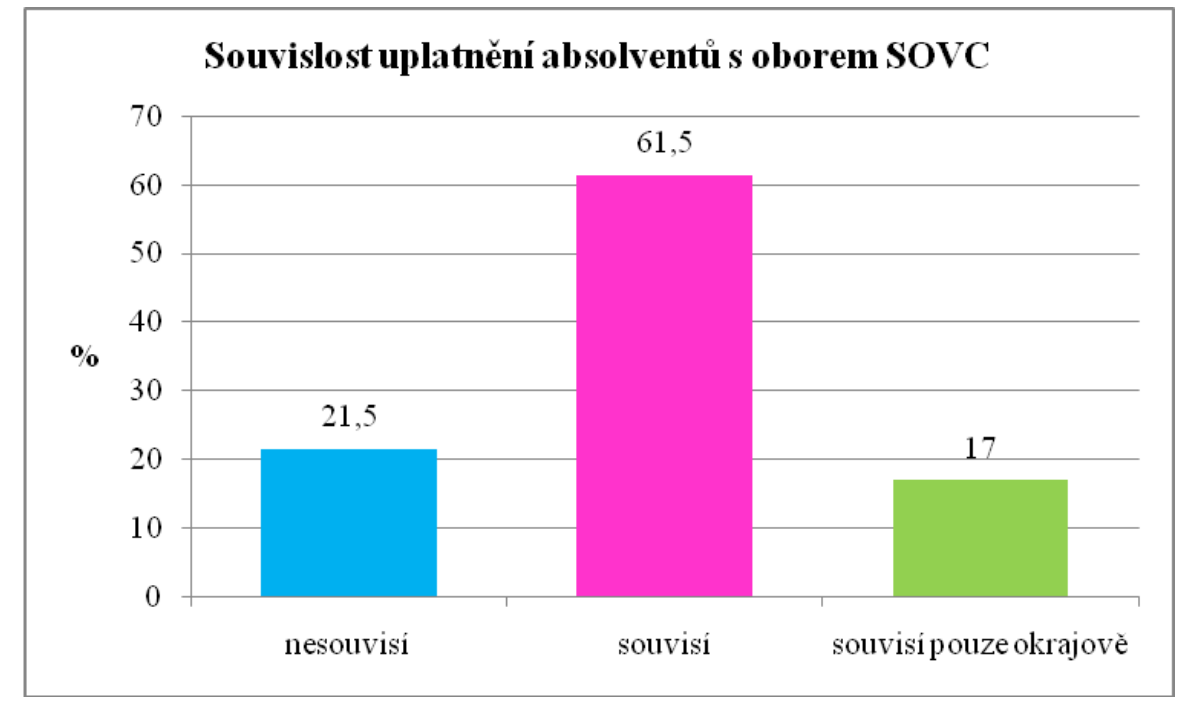

Obrázek 2. Graf - Souvislost uplatnění absolventů s oborem SOVC 
Absolventi, kteří našli uplatnění související s oborem SOVC tvoří 61,5 \%, což je vysoký podíl v souvislosti s tím, že absolventů, kteří našli uplatnění okrajově související s oborem SOVC je $17 \%$. Z toho tedy vyplývá, že absolventů, kteří pracují zcela mimo oblast svého vystudovaného oboru je pouze $21,5 \%$. Za hlavní výstupy dotazníkového šetření považujeme ty, které v rámci jejich uplatnění souvisí s náplní práce respondentů, typem organizací, cílovou skupinou atd. Vyplývá z nich, že absolventi oboru SOVC nacházejí své profesní uplatnění především v nízkoprahových zařízeních pro děti a mládež (16\%), neziskových organizacích a občanských sdruženích (14\%), Střediscích volného času (12\%), poradnách $(12 \%)$ atd. viz graf na obrázku 3.

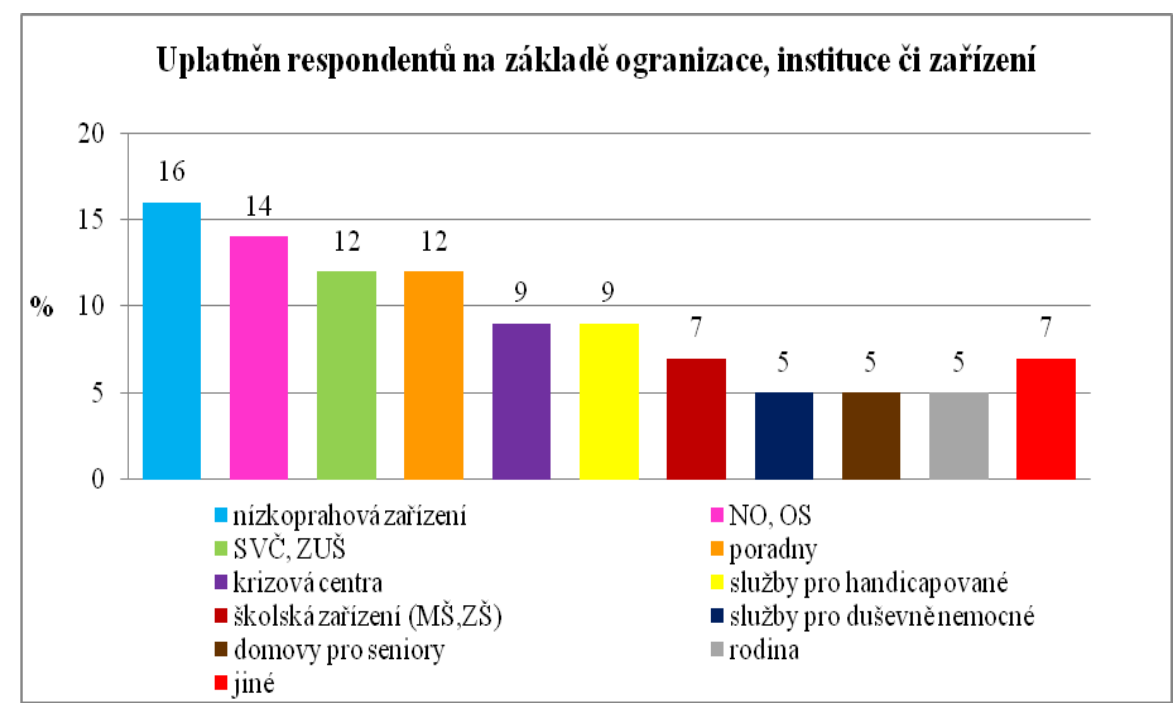

Obrázek 3. Graf - Uplatnění respondentů na základě organizace, instituce či zařízení.

Dle druhu činnosti či potřeby klienta se absolventi ve svém uplatnění nejčastěji zabývají poradenskou činností $(25 \%)$, náplní volného času (24 \%) a formálním vzděláváním $(24 \%)$ více viz graf na obrázku 4.

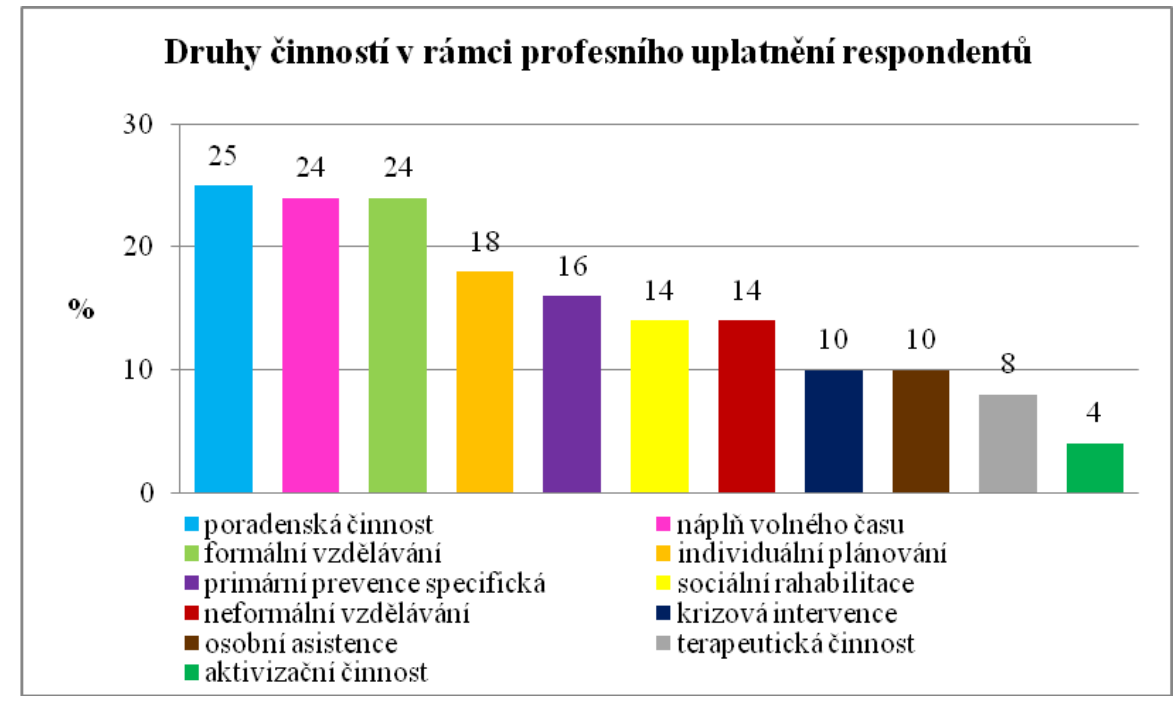

Obrázek 4. Graf - Druhy činnosti v rámci profesního uplatnění respondentů. 
Největší podíl absolventů působí v rámci primární prevence - nejvíce zastoupena cílová skupina ,zdravá populace“ v rámci uplatnění absolventů viz graf na obrázku 5.

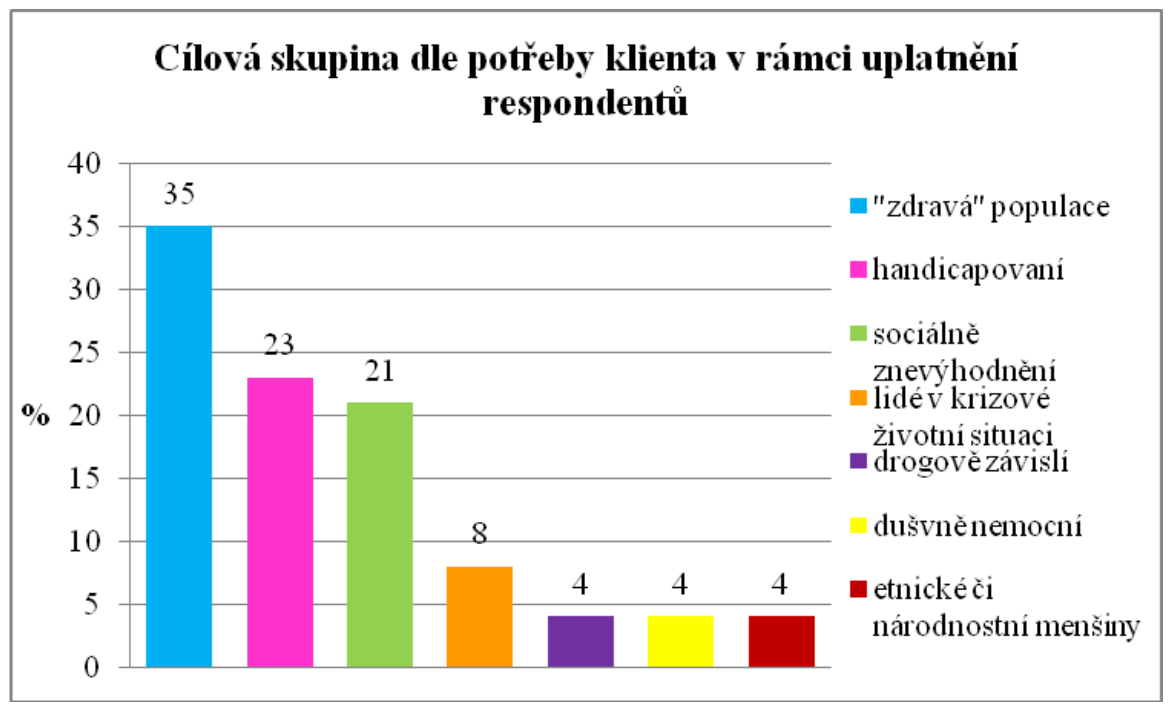

Obrázek 5. Graf - Cílová skupina dle potřeby klienta v rámci uplatnění respondentů.

Realizované dotazníkové šeření poukázalo na vysokou stálost profesních uplatnění respondentů, jež vyplývá z několika položek dotazníku:

- Dle doby působení ve svém současném uplatnění nejčastěji respondenti setrvávají ve svém současném zaměstnání 1-2 roky (22\%) a 2-3 roky (22\%). 3 roky je ve svém uplatnění $18 \%$ respondentů, 3-6 měsíců $17 \%$, 6-12 měsíců $14 \%$, a v tříměsíční zkušební době $6 \%$ respondentů.

- Většina respondentů pracuje ve svém současném uplatnění na plný úvazek (63\%), v rámci úvazku $0,5-1,0$ pracuje $20 \%$ respondentů, menší než poloviční má $8 \%$ respondentů.

- Pracovní smlouvu na dobu neurčitou má $51 \%$ respondentů, smlouvu na dobu delší než 2 roky (5\%) smlouvu na 1-2 roky (16\%), smlouvu do jednoho roku (28\%).

Zajímavý výsledek přineslo dotazníkové šetření $\mathrm{v}$ souvislosti $\mathrm{s}$ hledáním současného uplatnění respondentů, kdy $33 \%$ respondentů svoje uplatnění aktivně nehledalo, ale bylo jim nabídnuto. Z toho je patrné, že o absolventy oboru SOVC je v praxi značný zájem.

Potěšující zprávy pro sociální pedagogiku vyplývají z následujících výstupů. Značný podíl absolventů je ve svém současném uplatnění spokojených (určitě spokojen $38 \%$, spíše spokojen $51 \%$, spíše nespokojen $11 \%$ ). Vysoké procento absolventů se chce v budoucnu uplatnit v oblasti související s oborem SOVC (určitě ano $15 \%$, spíše ano $64 \%$, je mi jedno 15 $\%$, spíše ne $14 \%$, určitě ne $2 \%$ ).

\subsection{Q-třiděni}

Opět byla data převedena $\mathrm{z}$ IDN do programu MS Excel a upravena v požadovanou datovou matici pro možnost operací ve statistickém programu. Všechny statistické operace byly prováděny v softwaru statistického programu IBM SPSS Statistica 19. Pro zjištění preference Q-typů absolventy, které mělo za cíl zjistit, jak respondenti posuzují své vědomosti a 
dovednosti získané $\mathrm{v}$ rámci studia SOVC $\mathrm{v}$ souvislosti s jejich profesním uplatněním na trhu práce, byly použity součty kladných a záporných hodnocení a tedy dvojí pořadí Q-typů nejvíce preferované kladně hodnocené výroky (tedy s nejvyšším souhlasem respondentů) a nejvýše záporně hodnoceny Q-typy (tedy s nejmenším souhlasem respondentů).

\section{Výsledky výzkumu}

Respondenti staví př́nos studia SOVC v osobnostní rovině před přímo v rovině profesní. Z hlediska afektivních výukových dílů si respondenti nejvíce váží vztahů se studenty a vyučujícími katedry sociální pedagogiky a jejich přístupu. Za nejpřínosnější pro profesní praxi pak respondenti považují osvojení si velkého množství různorodých aktivit, včetně technik osobnostní přípravy, které mohou využít ve své profesní praxi s klienty. Dále jsme dospěli ke zjištění, že se respondenti necítí být dostatečně vybaveni znalostmi o krizové intervenci ze studia SOVC.

Pro hledání statisticky významných rozdílů mezi hodnoceními skupin pracujících a studujících respondentů u konkrétních Q-typů byla použita metoda zpracování dat Mann Whitney $U$ test pro dva nezávislé soubory. Signifikantní rozdíly byly zaznamenány pouze u dvou výroků. Oba tyto výroky spadají do afektivních výukových cílů, tzn., že se tyto dvě skupiny respondentů liší pouze $v$ oblasti afektivních výukových cílů a to jen velmi částečně. U ostatních Q-typů se hodnocení těchto dvou skupin významně neliší. Z toho lze vyvodit, že uplatnění respondentů $\mathrm{v}$ praxi nemá vliv na hodnocení př́nosu studia v porovnání se studujícími absolventy.

Dále byla provedena korelační analýza za účelem odhalení statisticky významných vztahů mezi hodnoceními jednotlivých respondentů. Pro tuto operaci byl použit Spearmanưv korelačni koeficient. Byly zaznamenány dvě silné korelace $(0,745$ a 0,723 na hladině významnosti $\alpha=0,05)$. Mezi těmito silně korelujícími respondenty nebyly nalezeny žádné relevantní společné znaky $\mathrm{v}$ datech z dotazníkového šetření. Nebyl tedy nalezen faktor, který by tyto korelace objasnil.

Ve faktorové analýze nám pro vysvětlení $100 \%$ variability proměnných vyšlo 19 faktorů. Při omezení počtu faktorů na pět nám FA popisovala pouze $50 \%$ variability. Dále jsme se FA v našem výzkumném šetření tedy nezabývali. Z těchto výsledků bylo zřejmé, že odpovědi jsou velmi heterogenní. To mohlo být způsobeno př́lišnou různorodostí a zároveň malým rozsahem výzkumného vzorku.

\section{Závěr}

$\mathrm{V}$ rámci výzkumné studie se nám podařilo zmapovat oblast profesního uplatnění absolventů oboru Sociální pedagogika a volný čas. Udělali jsme si představu o prŕnosu studia SOVC pro jejich absolventy po stránce profesní, osobnostní i hodnotové. Dále se podařilo prozkoumat analytické možnosti Q-metodologie a srovnat je s odlišným druhem měření dat.

Potvrdilo se, že pro preferenci hodnocení daných témat je Q-metodologie opravdu účinný nástroj. Domníváme se, že předložená práce a její závěry skýtají podněty pro další pokračování formou výzkumných šetření. Př́nos výstupů výzkumného šetření spatřujeme především v jejich aplikaci jako jisté zpětné vazby a zpětných informací oboru SOVC. Z výstupů z druhé části výzkumného šetření mohou být vypracována doporučení na doplnění a obohacení obsahu studia oboru SOVC. 
část : c

Mápověda k vrohování

\begin{tabular}{|c|c|c|c|c|c|c|}
\hline $\begin{array}{l}\text { Minimální } \\
\text { souhlas }\end{array}$ & & & Nĕco mezi & & & $\begin{array}{l}\text { Maximální } \\
\text { souhilas }\end{array}$ \\
\hline 1 výrok & $\begin{array}{l}\text { 3 výroky } \\
\text { Zde uber } \\
1 \text { výrok }\end{array}$ & $\begin{array}{l}10 \text { výrok8 } \\
\text { Zde přidej } \\
1 \text { výrok }\end{array}$ & 14 výrok8 & $\begin{array}{l}10 \text { výrok8 } \\
\text { Zde uber } \\
1 \text { výrok }\end{array}$ & $\begin{array}{l}3 \text { výroky } \\
\text { Zde př́idej } \\
1 \text { výrok }\end{array}$ & 1 výrok \\
\hline \multirow[t]{23}{*}{ 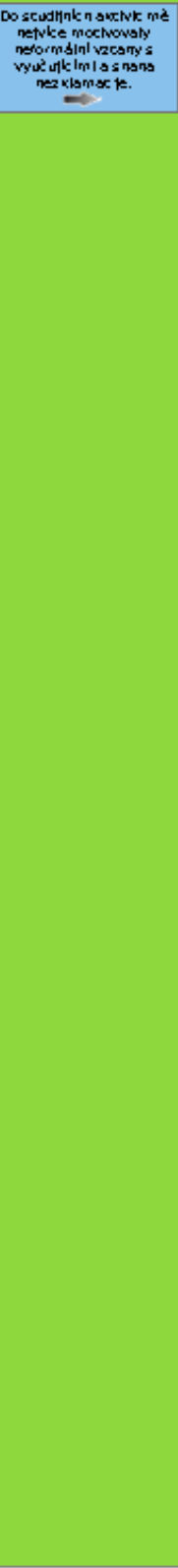 } & \multirow{2}{*}{ 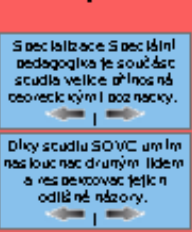 } & 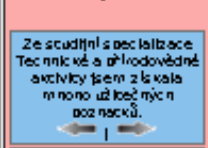 & \multirow{2}{*}{ 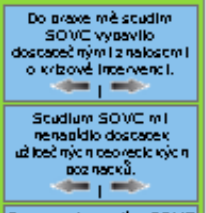 } & \multirow{2}{*}{ 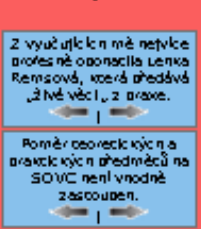 } & \multirow{2}{*}{ 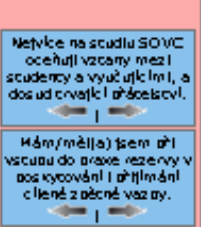 } & 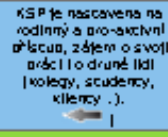 \\
\hline & & \multirow{3}{*}{ 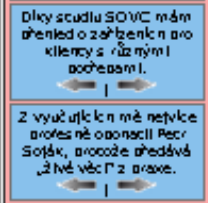 } & & & & \\
\hline & 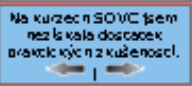 & & 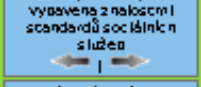 & \multirow{2}{*}{ 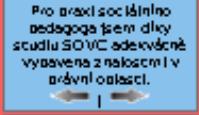 } & & \\
\hline & \multirow{3}{*}{ 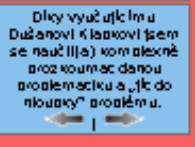 } & & 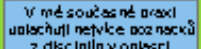 & & & \\
\hline & & \multirow{4}{*}{ 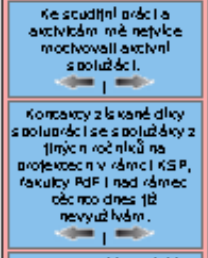 } & 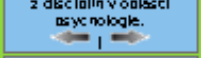 & \multirow{2}{*}{ 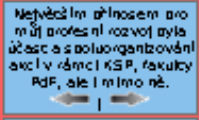 } & & \\
\hline & & & \multirow{4}{*}{ 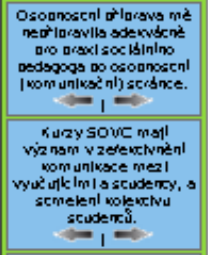 } & & & \\
\hline & & & & \multirow{2}{*}{ 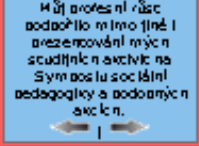 } & & \\
\hline & & & & & & \\
\hline & & \multirow{3}{*}{ 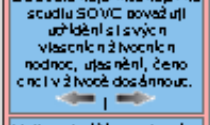 } & & \multirow{2}{*}{ 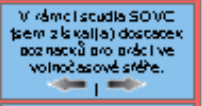 } & & \\
\hline & & & 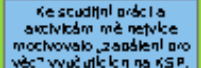 & & & \\
\hline & & & $80 x-1=0$ & \multirow{2}{*}{ 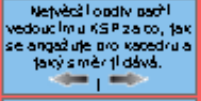 } & & \\
\hline & & \multirow{7}{*}{ 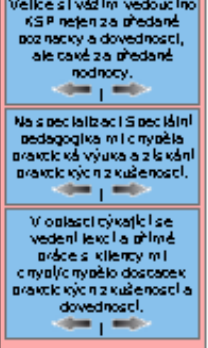 } & 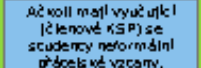 & & & \\
\hline & & & doxsitou $28<$ nows: & \multirow{5}{*}{ 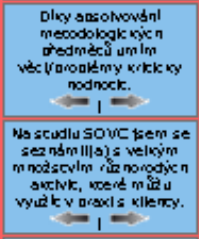 } & & \\
\hline & & & 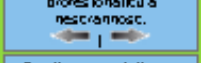 & & & \\
\hline & & & \multirow{2}{*}{ 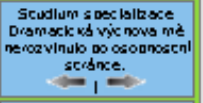 } & & & \\
\hline & & & & & & \\
\hline & & & \multirow{3}{*}{ 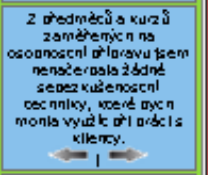 } & & & \\
\hline & & & & \multirow{2}{*}{ 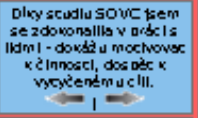 } & & \\
\hline & & & & & & \\
\hline & & & 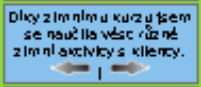 & \multirow[t]{4}{*}{ 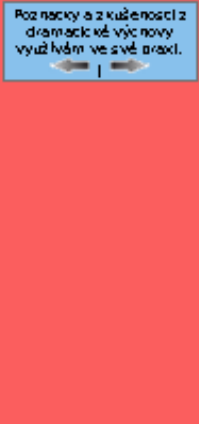 } & & \\
\hline & & & 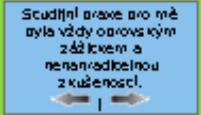 & & & \\
\hline & & & 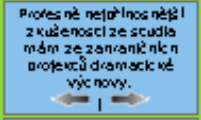 & & & \\
\hline & & & 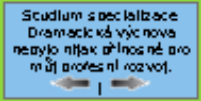 & & & \\
\hline
\end{tabular}

Pro ukončení dotazníku, prosím srovnejte všechny sloupečky dle pokynư.

(c) Lenka Kristková \& Zdeněk Janda 2010 - 2011 | Created by Stranky na míru

Obrázek 6. Závěrečná fáze Q-třídění Interaktivního dotazovacího nástroje. 


\section{Literatura}

Kristková, L. (2011). Profesní uplatnění sociálních pedagogů na trhu práce. (Diplomová práce). Brno: PdF MU.

\section{Kontakt}

Mgr. Petr Soják, Ph.D.

Masarykova univerzita

Pedagogická fakulta, Katedra sociální pedagogiky

Poříčí 7, 60300 Brno

e-mail:sojak@ped.muni.cz

Mgr. Lenka Kristková

Za Potokem 49, 59501 Velká Bíteš

e-mail: LenkaKristkova@gmail.com

\section{Bibliografické údaje}

Soják, P., \& Kristková, L. (2011). Mapování profesního uplatnění sociálních pedagogů na trhu práce od roku 2005-2011. In T. Janík, P. Knecht, \& S. Šebestová (Eds.), Smišený design v pedagogickém výzkumu: Sborník př́spěvkĩ z 19. výročni konference České asociace pedagogického výzkumu (s. 200208). Brno: Masarykova univerzita.

Dostupné z: http://www.ped.muni.cz/capv2011/sbornikprispevku/sojakkristkova.pdf doi: 10.5817/PdF.P210-CAPV-2012-68 